\title{
Characterization of nine transferred SSR markers in the tropical tree species Enterolobium contortisiliquum (Fabaceae)
}

\author{
P.A. Moreira', S.A.S. Sousa ${ }^{2}$, F.A. Oliveira ${ }^{2}$, N.H. Araújo ${ }^{2}$, \\ G.W. Fernandes ${ }^{1}$ and D.A. Oliveira ${ }^{2}$ \\ ${ }^{1}$ Laboratório de Ecologia Evolutiva e Biodiversidade, \\ Instituto de Ciências Biológicas, Universidade Federal de Minas Gerais, \\ Belo Horizonte, MG, Brasil \\ ${ }^{2}$ Laboratório de Bioprospecção e Recursos Genéticos, \\ Universidade Estadual de Montes Claros, Montes Claros, MG, Brasil
}

This study is part of a thesis presented by P.A. Moreira to the Universidade Federal de Minas Gerais in partial fulfillment of the requirements for the Doctoral degree. Corresponding author: P.A. Moreira

E-mail: patriciadabreu@yahoo.com.br

Genet. Mol. Res. 11 (4): 3729-3734 (2012)

Received November 7, 2011

Accepted March 6, 2012

Published August 17, 2012

DOI http://dx.doi.org/10.4238/2012.August.17.11

\begin{abstract}
Transfer of molecular markers is widely used in conservation genetic studies. We investigated the transferability of simple sequence repeat (SSR) markers developed for Enterolobium cyclocarpum to E. contortisiliquum, a tropical tree widely distributed in dry forests. A set of 9 evaluated SSR markers were amplified in $E$. contortisiliquum and the degree of polymorphism was assessed in 8 trees sampled from each of 5 populations from central Brazil. All loci were polymorphic and the mean number of alleles for all loci was 6 . In addition, all pairs of SSR markers were in linkage equilibrium. For most loci, the observed heterozygosity was higher than the expected heterozygosity under Hardy-Weinberg equilibrium, with fixation indices not significantly different from zero. The combined probability of paternity exclusion was high and the probability of identity was very
\end{abstract}


low. We conclude that these SSR markers developed for E. cyclocarpum are applicable for genetic studies of E. contortisiliquum.

Key words: Simple sequence repeats; Marker transferability; Tropical seasonally dry forest; Enterolobium contortisiliquum

\section{INTRODUCTION}

Molecular markers are an efficient tool for detecting polymorphism at the DNA level. Many molecular markers are available, but studies with microsatellite or simple sequence repeats (SSRs) have increased during the last decade. SSR molecular markers have many advantages because they are highly polymorphic, robust, codominant, and easily detected by polymerase chain reaction (PCR). In addition, SSR markers are widespread in genomes (Goldstein and Schlotterer, 1999). Despite these positive qualities, however, the development of SSR markers is time-consuming and expensive. Therefore, cross-species amplification is an effective alternative for the application of this molecular tool to the study of ecological issues in high-diversity tropical ecosystems because it eliminates the labor and cost involved in developing SSR markers for new species (Cristofani-Yali et al., 2011). Because of the rapid fragmentation of natural habitats and the long time needed to develop SSR markers, the transferability of these molecular markers among related species is an efficient tool for protecting and managing populations. SSR molecular markers can provide important information that is used by conservation genetics to evaluate and monitor species (Frankham et al., 2002).

Heterologous amplification of SSR markers has been successfully applied to the genetic analysis of tropical tree species (Zucchi et al., 2002). The transfer of polymorphic markers in plants is mainly successful within genera. Many studies have demonstrated the use of SSR markers developed from one species to another of the same genus. This transfer occurs because of sequence conservation in the primer sites flanking the microsatellite loci and the stability of those sequences during evolution (Dayanandan et al., 1997; Ciampi et al., 2008; Feres et al., 2009).

Enterolobium contortisiliquum (Vell.) Morong (Leguminosae) is a poisonous tropical tree species that has been removed from natural areas owing to the advance of cattle production and agriculture in central Brazil. The ingestion of E. contortisiliquum pods is harmful to cattle, causing abortion and severe injuries in the skin, mainly in photosensitive places without pigmentation (Bonel-Raposo et al., 2008; Costa et al., 2009). Therefore, many farmers have cut trees of this species near their ranches because the fruiting period of E. contortisiliquum occurs during the dry season, coincident with low forage availability. Molecular markers are needed to understand the effects of fragmentation and selective logging in this tree species and to generate useful information for its conservation.

To save time in E. contortisiliquum conservation, we aimed to evaluate in E. contortisiliquum the transferability and characterization of SSR molecular markers previously developed for Enterolobium cyclocarpum. These SSR markers may be a valuable tool for the investigation of the genetic diversity, mating system, gene flow, and spatial genetic structure of this species. 


\section{MATERIAL AND METHODS}

Five populations of E. contortisiliquum in different tropical dry forests were sampled, 4 in Minas Gerais State (Unaí, Felícios dos Santos, Montes Claros and Manga, respectively, UNA, FES, MOC, and MAN) and 1 in Bahia State (Vitória da Conquista, VIC). The shortest distance between these populations was $170 \mathrm{~km}$ (between FES and MOC), and the longest was $674 \mathrm{~km}$ (between UNA and VIC; Figure 1). In each population, expanded leaves from 8 reproductive trees of E. contortisiliquum were collected and stored in silica gel until DNA extraction. Genomic DNA extraction was carried out using a standard cetyltrimethylammonium bromide procedure (Doyle and Doyle, 1990). The concentration of DNA extracted was quantified visually on $1.0 \%$ agarose gel through comparison with standard DNA concentrations. The DNA was diluted in TE buffer $(10 \mathrm{mM}$ Tris- $\mathrm{HCl}, \mathrm{pH}$ 8.0 , and $1 \mathrm{mM}$ ethylenediaminetetraacetic acid) to a final concentration of $3 \mathrm{ng} / \mu \mathrm{L}$ before PCR amplifications.

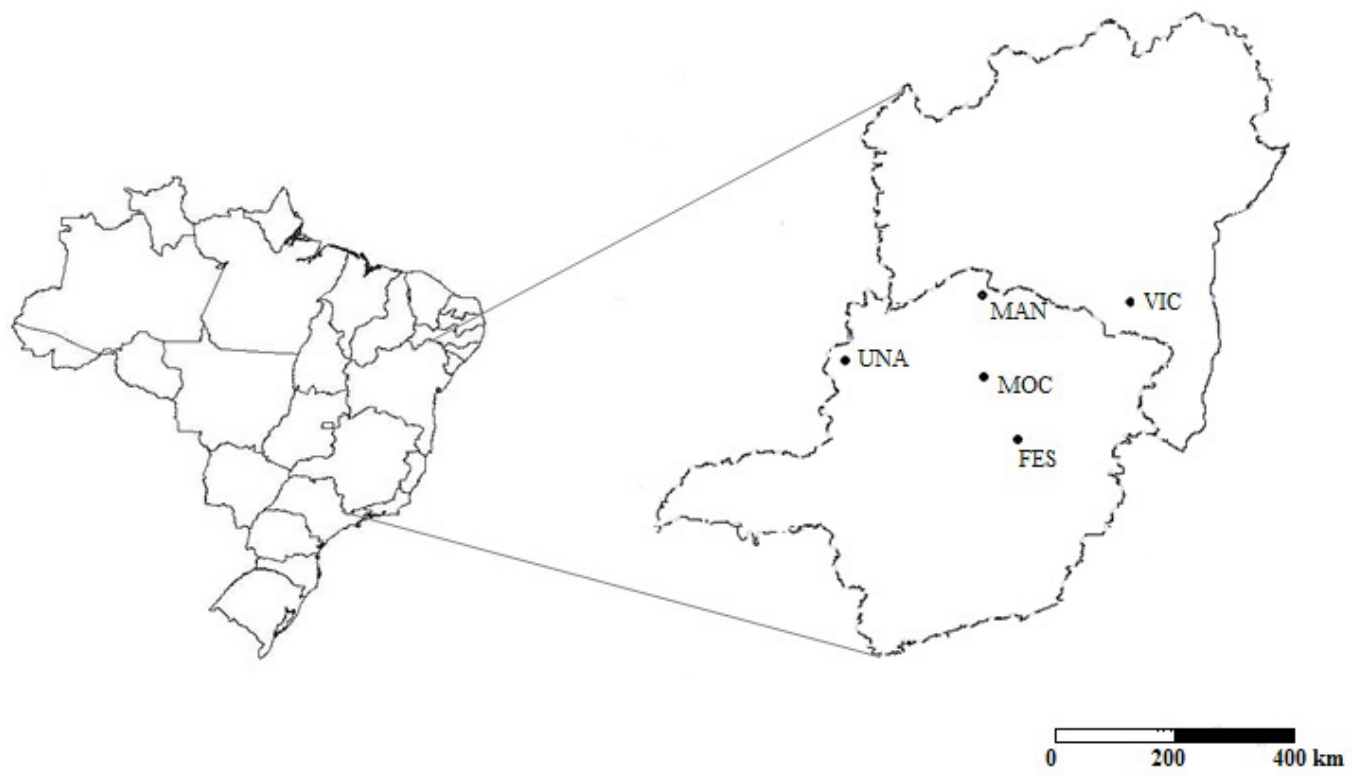

Figure 1. Localization of the populations of Enterolobium contortisiliquum of central Brazil. UNA = Unaí; MAN $=$ Manga MOC $=$ Montes Claros; FES $=$ Felícios dos Santos; VIC $=$ Vitória da Conquista .

Nine microsatellite loci previously developed for the Guanacaste tree E. cyclocarpum (Peters et al., 2008) were used for PCR amplification in E. contortisiliquum. Microsatellite amplifications were performed in a $10-\mu \mathrm{L}$ volume containing $10.0 \mu \mathrm{M}$ of each primer, $1 \mathrm{U}$ Taq DNA polymerase, $250 \mu \mathrm{M}$ of each deoxyribonucleotide triphosphate, $1 \mathrm{X}$ reaction buffer (10 $\mathrm{mM}$ Tris- $\mathrm{HCl}, \mathrm{pH} 8.3,50 \mathrm{mM} \mathrm{KCl}$, and $1.5 \mathrm{mM} \mathrm{MgCl}_{2}$ ), $0.25 \mu \mathrm{g}$ bovine serum albumin, and 9.0 ng template DNA. Amplifications were performed using a Veriti ${ }^{\circledR}$ Thermal Cycler (Applied Biosystems) under the following conditions: $94^{\circ} \mathrm{C}$ for $5 \mathrm{~min}$ (one cycle); $94^{\circ} \mathrm{C}$ for $1 \mathrm{~min}$, $54-58^{\circ} \mathrm{C}$ for $1 \mathrm{~min}$ (according to the primer), and $72^{\circ} \mathrm{C}$ for $1 \mathrm{~min}\left(35\right.$ cycles), and $72^{\circ} \mathrm{C}$ for 
30 min (one cycle). The PCR products were genotyped on a 3500 Genetic Analyzer (Applied Biosystems) and were sized through comparison to a GeneScan ${ }^{\mathrm{TM}} 600$ LIZ $^{\circledR}$ Size Standard (Applied Biosystems). Fluorescent PCR products were automatically sized using GeneMapper ${ }^{\mathbb{R}}$ (Applied Biosystems).

SSR loci were characterized based on 40 adult individuals for the number of alleles per locus and observed and expected heterozygosities under Hardy-Weinberg equilibrium (Nei, 1978). The inbreeding coefficient, for each locus and over all loci, was also estimated (Nei, 1978). All pairs of loci were tested for linkage equilibrium. Analyses and randomization-based tests with Bonferroni's correction were performed with FSTAT 2.9.3.2 (Goudet et al., 1996; Goudet, 2002). The probability of genetic identity (I) (Chakravaratt and Li, $1983)$ and the probability of paternity exclusion $(Q)$ (Weir, 1996) were estimated for each locus, and the combined probability of genetic identity, $I C=\Pi I i$, and combined probability of paternity exclusion, $Q C=1-[\Pi(1-Q i)]$, were estimated for the loci overall.

\section{RESULTS}

The set of SSR primers of E. cyclocarpum exhibited amplification in E. contortisiliquum under various annealing temperatures (Table 1). All loci were polymorphic, and the average allele number over all loci was 6 , with the number of alleles ranging from three (Ency-21 and Ency-22) to 11 (Ency-24; Table 2). All microsatellite loci pairs were in linkage equilibrium $(\mathrm{P}>0.001389$, adjusted nominal 5\% level with Bonferroni's correction).

Table 1. Description of simple sequence repeat primers developed for Enterolobium cyclocarpum and transferred to E. contortisiliquum with repeat motif of each loci, the allele size range founded in E. contortisiliquum for each loci and the annealing temperature (Ta) of each primer used for E. contortisiliquum.

\begin{tabular}{lccc}
\hline Locus & Repeat motif & Allele size range $(\mathrm{bp})$ & Ta $\left({ }^{\circ} \mathrm{C}\right)$ \\
\hline Ency-04 & $(\mathrm{AC})_{9} \ldots(\mathrm{ACAT})_{4} \ldots(\mathrm{AAAC})_{5}$ & $164-202$ & 56 \\
Ency-08 & $(\mathrm{AAAG})_{4}$ & $192-206$ & $158-172$ \\
Ency-09 & $(\mathrm{AG})_{16}$ & $204-220$ & 58 \\
Ency-13 & $(\mathrm{ATC})_{10}$ & $266-282$ & 58 \\
Ency-17 & $(\mathrm{GTTT})_{6}$ & $192-198$ & 56 \\
Ency-21 & $(\mathrm{AC})_{8} \ldots(\mathrm{ACAT})_{12}$ & $192-198$ & 56 \\
Ency-22 & $(\mathrm{CT})_{14} \ldots(\mathrm{ACTC})_{4}$ & $106-136$ & 56 \\
Ency-24 & $(\mathrm{CT})_{15}$ & $124-150$ & 54 \\
Ency-33 & $(\mathrm{ACAT})_{8}$ & & 54 \\
\hline
\end{tabular}

For most loci, the observed heterozygosity was higher than that expected under Hardy-Weinberg equilibrium, with fixation indices not statistically different from zero (see Table 2). Nevertheless, the combined probability of paternity exclusion was high $(Q C=$ $0.9929)$ and the probability of identity was very low $\left(\sim 10^{-36}\right.$; see Table 2$)$, showing that the battery of loci is appropriate for population genetic analyses. The cross-transferability of Guanacaste tree SSR markers to E. contortisiliquum observed in this study renders this set of primers useful for investigating the structure and genetic diversity of E. contortisiliquum populations. 
Table 2. Characterization of the genetic diversity of nine primers developed for Enterolobium cyclocarpum and transferred to E. contortisiliquum.

\begin{tabular}{lrccccc}
\hline Locus & $N_{\mathrm{A}}$ & $H_{\mathrm{E}}$ & $H_{\mathrm{O}}$ & $f$ & $Q$ & \multicolumn{1}{c}{} \\
\hline Ency-04 & 9 & 0.657 & 0.750 & -0.144 & 0.4211 & 0.0000 \\
Ency-08 & 6 & 0.644 & 0.833 & -0.300 & 0.4306 & 0.0000 \\
Ency-09 & 4 & 0.579 & 0.278 & $0.524^{*}$ & 0.3105 & 0.0004 \\
Ency-13 & 4 & 0.692 & 0.516 & 0.257 & 0.4340 & 0.0000 \\
Ency-17 & 5 & 0.630 & 0.150 & $0.764^{*}$ & 0.3779 & 0.0000 \\
Ency-21 & 3 & 0.628 & 1.000 & -0.610 & 0.3638 & 0.0001 \\
Ency-22 & 3 & 0.601 & 0.472 & 0.216 & 0.3302 & 0.0002 \\
Ency-24 & 11 & 0.848 & 0.917 & -0.082 & 0.6826 & 0.0000 \\
Ency-33 & 9 & 0.536 & 0.639 & -0.195 & 0.3463 & $I C=1.004 \times 10^{-36}$ \\
Average & 6 & 0.646 & 0.617 & 0.045 & $Q C=0.9929$ & 0.002 \\
\hline
\end{tabular}

$N_{\mathrm{A}}=$ number of alleles; $H_{\mathrm{E}}=$ expected heterozygosity; $H_{\mathrm{O}}=$ observed heterozygosity; $f=$ inbreeding coefficient; $Q$ = probability of paternity exclusion; $Q C$ = combined probability of paternity exclusion; $I=$ probability of genetic identity; $I C=$ combined probability of genetic identity. Values followed by asterisks are statistically different from zero, for $\mathrm{P}=0.005$ (Bonferroni's adjusted $\mathrm{P}$ value for a nominal level of 5\%).

\section{DISCUSSION}

SSR molecular markers derived from E. cyclocarpum were successfully transferred to E. contortisiliquum in our study, confirming that the regions flanking these microsatellites are conserved enough to permit locus amplification. The transfer of SSR markers is unequally distributed across taxa, but a high success of SSR transferability is found within plant genera (reaching rates close to $60 \%$ in eudicots) (Barbará et al., 2007). The SSR transferability for Leguminosae species, including Enterolobium species, has been successfully reported. Six pairs of primers developed for the tropical rain forest tree Pithecellobium elegans could amplify SSR fragments in Enterolobium schomburgkii, and three of these could do so in E. cyclocarpum (Dayanandan et al., 1997).

Our results show that the polymorphism level founded in E. contortisiliquum is satisfactory. In fact, the high percentage transfer capability of Guanacaste tree SSR markers to $E$. contortisiliquum observed in this study makes these molecular markers valuable tools for the investigation of the genetic diversity, mating system, gene flow, and spatial genetic structure of $E$. contortisiliquum populations.

\section{ACKNOWLEDGMENTS}

We thank Universidade Estadual de Montes Claros for logistical support during our laboratory work. We also thank F.S. Neves for help with field work and E.V. Menezes for help with laboratory work. We are grateful to J. Lobo for his comments on the early versions of this manuscript. We gratefully acknowledge a postgraduate scholarship to P.A. Moreira from Coordenação de Aperfeiçoamento de Pessoal de Nível Superior (CAPES), a scholarship of Fundação de Amparo à Pesquisa do Estado de Minas Gerais (PIBIC/FAPEMIG) to F.A. Oliveira and a scholarship of Universidade Estadual de Montes Claros (BIC/UNI-UNIMONTES) to S.A.S. Sousa. We thank Fundação de Amparo à Pesquisa de Minas Gerais (FAPEMIG; \#APQ-00372-11) for support. 


\section{REFERENCES}

Barbará T, Palma-Silva C, Paggi GM, Bered F, et al. (2007). Cross-species transfer of nuclear microsatellite markers: potential and limitations. Mol. Ecol. 16: 3759-3767.

Bonel-Raposo J, Riet-Correa F, Guim TM, Schuch ID, et al. (2008). Intoxicação aguda e abortos em cobaias pelas favas de Enterolobium contortisiliquum (Leg. Mimosoideae). Pesq. Vet. Bras. 28: 593-596.

Chakravaratt I and Li CC (1983). The effect of linkage on paternity calculations. In: Inclusion Probabilities in Parentage Testing (Walkera RH, ed.). American Association of Blood Banks, Arlington, 411-420.

Ciamp AY, Azevedo VCR, Gaiotto FA, Ramos ACS, et al. (2008). Isolation and characterization of microsatellite loci for Hymenaea courbaril and transferability to Hymenaea stigonocarpa, two tropical timber species. Mol. Ecol. Resour. 8: 1074-1077.

Costa RLD, Marini A, Tanaka D, Berndt A, et al. (2009). Intoxication of bovines by Enterolobium contortisiliquum (Timboril) in Brazil. Arch. Zootec. 58: 313-316.

Cristofani-Yali M, Novelli VN, Bastianel M and Machado MA (2011). Transferibility and level of heterozygosity of microsatellite markers in Citrus species. Plant. Mol. Biol. Rep. 29: 418-423.

Dayanandan S, Bawa K and Kesseli R (1997). Conservation of microsatellites among tropical trees (Leguminosae). Am. J. Bot. 84: 1658.

Doyle JJ and Doyle JL (1990). Isolation of plant DNA from fresh tissue. Focus 12: 13-15.

Feres JM, Martinez ML, Martinez CA, Mestriner MA, et al. (2009). Transferability and characterization of nine microsatellite markers for the tropical tree species Tabebuia roseo-alba. Mol. Ecol. Resour. 9: 434-437.

Frankham R, Ballou JD and Briscoe DA (2002). Introduction to Consevation Genetics. Cambridge University Press, Cambridge.

Goldstein DB and Schlotterer C (1999). Microsatellites: Evolution and Applications. Oxford University Press, Oxford.

Goudet J (2002). FSTAT, A Program to Estimate and Test Gene Diversities and Fixation Indices (Version 2.9.3.2). Available at [http://www.unil.ch/izea/softwares/fstat.html]. Accessed July 3, 2011.

Goudet J, Raymond M, de MT and Rousset F (1996). Testing differentiation in diploid populations. Genetics 144: 1933 1940.

Nei M (1978). Estimation of average heterozygosity and genetic distance from a small number of individuals. Genetics 89: $583-590$.

Peters MB, Hagen C, Trapnell DW, Hamrick JL, et al. (2008). Isolation and characterization of microsatellite loci in the Guanacaste tree, Enterolobium cyclocarpum. Mol. Ecol. Resour. 8: 129-131.

Weir BS (1996). Genetic Data Analysis II: Methods for Discrete Population Genetic Data. Sinauer Associates, Inc., Sunderland.

Zucchi MI, Brondani RPV, Pinheiro JB, Brondani C, et al. (2002). Transferability of microsatellite markers from Eucalyptus spp. to Eugenia dysenterica (Myrtaceae family). Mol. Ecol. Notes 2: 512-513. 